\title{
Buruli Ulcer in Animals and Experimental Infection Models
}

\author{
Miriam Bolz and Marie-Thérèse Ruf
}

\section{$1 \quad$ Naturally Infected Animals}

Naturally infected animals presenting with typical BU lesions have so far only been described in Australia and there only in one major endemic focus, the central coastal Victoria close to Melbourne. Between 1980 and 1985, 11 M. ulcerans positive koalas (Phascolarctos cinereus) in a population of approximately 200 koalas on Raymond Island were described as having ulcers on the face, forearm, rump, groin or foot pad [1, 2]. More recently, examination of common ringtail (Pseudocheirus peregrinus) and common brushtail (Trichosurus vulpecula) possums from Point Lonesdale, a small BU endemic region with a recent human outbreak, revealed that $38 \%$ of the analyzed ringtail possums and $24 \%$ of the brushtail possums had laboratory-confirmed $M$. ulcerans skin lesions and/or their feces tested positive for M. ulcerans DNA by PCR. Lesions were found on tails, toes, feet and noses with the majority occurring on the tail [3]. Another study by O'Brien et al. showed that $M$. ulcerans bacteria were present in possum lesions and from $90 \%$ of the animals with lesions, positive cultures could be obtained [4]. The high number of possums with skin lesions suggests that possums may represent an animal reservoir for $M$. ulcerans in south-eastern Australia [3-5].

Sporadically, M. ulcerans positive lesions were also diagnosed in domesticated animals like dogs [6], a cat [7], horses [8] and alpacas [9]. In the dogs, lesions were found on the feet, legs and the rump and diagnosis was done by IS2404 real-time PCR (qPCR). Molecular typing in three animals confirmed that the infection was caused by disease-causing human strains [6]. The cat presented with a lesion on the nose and acid fast bacilli (AFB) staining as well as molecular methods confirmed the infection with M. ulcerans [7].

Despite considerable effort, several studies conducted in Africa were not able to corroborate the findings from Australia [10-12].

M. Bolz (ه) • M.-T. Ruf

Swiss Tropical and Public Health Institute, Basel, Switzerland 


\section{$2 \quad$ The Mouse (Mus musculus) Model}

\subsection{History of the BU Mouse Model}

Already with the first documentation of BU and its causative agent $M$. ulcerans, the description of potential animal models was published. Besides the report of the clinical picture and the cultivation of the new mycobacterial species, MacCallum et al. dedicated two separate chapters of their publication in 1957 to "Experimental investigations in laboratory animals" and the description of the "pathology of the experimental lesions in the rat" [13]. In their attempt to grow the unknown mycobacteria, the researchers conducted a series of experiments in guinea pigs, rats and mice, mostly injecting ground-up tissue of a patient lesion or exudate from a patient's ulcer. As a next step they serially passaged a saline extract of lung tissue from infected animals that had died. None of the rats showed any signs of disease. Curiously, the rat of the fourth passage was forgotten and 16 months after intraperitoneal (i.p.) injection developed edematous and ulcerated limbs and the tail sloughed off. Microscopic examination of ulcers revealed high numbers of AFB, thus the rat became the first animal to sustain $M$. ulcerans and characterize the bacteria while optimal in vitro growth conditions still had to be found [13]. Beside the rats, the scientists also reported the infection of 16 white mice, 12 guinea-pigs, two rabbits, one fowl and three lizards and made observations that would be re-confirmed in many more animal studies to follow: mice seemed more susceptible to infection than rats and guinea-pigs.

The actual development of the most commonly used animal model in BU research today, the mouse (Mus musculus), traces back to Fenner [14], who used it primarily for the evaluation of available antimicrobial compounds against the newly discovered $M$. ulcerans bacteria $[14,15]$. In those early days of BU research, the mouse model was used to study all the major aspects of the disease that would later regain interest: chemotherapy testing [16], characterization of the immune response against $M$. ulcerans [17] and pathogenesis [18].

During the next 20 years, animal models in BU research were only occasionally used, but importantly, the knowledge gained from previous studies served as a basis for the development of the mouse model for Mycobacterium leprae infection, the cause of leprosy [19]. A first grading system for assessing disease severity in the mouse model was described in 1972 in the context of drug testing [20] and further refinement of the mouse model to how it is mainly used today (foot pad injection) was then described in 1975 [21], a publication that reconfirmed the relative resistance of guinea pigs to $M$. ulcerans infection once more.

For another 20-30 years BU animal models were nearly forgotten again, before an increasing number of publications reflected the regained interest in the topic. The animal model that emerged as most commonly used was the mouse. Its applications can be roughly split into four different topics as further elaborated in this chapter: testing of antimicrobial compounds, vaccine development, study of the pathogenesis of BU and studies on the toxin mycolactone. 


\subsection{Experimental Infection of the Mouse}

\subsubsection{Infection Sites}

Very early in BU research and the use of the mouse model it was recognized that $M$. ulcerans needs a relatively cold location to grow in the mouse body [16, 18]. Even when animals were inoculated intracerebrally, the most vulnerable site of infection remained to be the tail [18]. Conveniently, low temperatures in mice are found in places that are not extensively covered with fur: the tail, the hind foot pads and the ears. Each of the three sites have their practical advantages and disadvantages; for example, the ears are very thin structures, which makes injection of bacteria challenging but on the other hand processing for histopathology is easy as there are no bones that have to be softened by decalcification, like it is the case in mouse foot pads. However, mouse ears do not contain a lot of fat tissue; hence they are very rarely used as site of infection, as $M$. ulcerans is mostly located close to fat cell areas in the human skin [22,23]. It appears that nowadays, the few laboratories that use mice as animal models for BU have a preference for either infecting the tail [24-26] or the foot pads [27-33]. A recent study by Bénard et al. compared a new infection site, the hock, to the foot pad and the ear, concluding that in their hands the foot pad is the site of choice in the mouse for a well-defined, consistent and reproducible infection [34].

\subsubsection{Mouse Strains}

The mouse strains used for infection with M. ulcerans in different laboratories are not overly diverse. While earlier studies had used outbred Swiss mice [28], the vast majority of newer studies used immunocompetent inbred strains that are very frequently used in research in general: BALB/c [24, 28, 30, 35-37] and C57BL/6 mice $[22,32,38]$ provided by different suppliers. Furthermore, a lot of studies did not use mixed sex mice but were only conducted in female animals. Again, depending on the laboratory, there seems to be a certain preference, rendering female BALB/c the most used mice for the BU mouse foot pad model by far. The first publication directly comparing the two most commonly used inbred strains, with each other and to infection in FVB/N mice was published in 2016 [25]. While infection led to ulceration of the tails and subsequent death of the animals in BALB/c and C57BL/6 mice, FVB/N mice were able to spontaneously heal the developed ulcers and did not succumb to the infection, regardless of the different $M$. ulcerans strains used in the study [25]. The only other study published on the specific topic of mouse strain comparability reported that C57BL/6 might be slightly more susceptible to the infection, displaying increased leukocyte infiltration and bacterial growth compared to $\mathrm{BALB} / \mathrm{c}$ mice [34].

Immunocompromised or transgenic mice were occasionally used to study the role of host factors in M. ulcerans infection. TNF receptor P55-deficient mice were shown to be equally susceptible to infection with highly virulent $M$. ulcerans strains as wild-type C57BL/6 mice, but showed increased susceptibility to non- and intermediately virulent strains [39]. Bieri et al. documented the infection in interferon- $\gamma$ (IFN $\gamma$ )-deficient mice (B6.129S7-Ifng $\left.{ }^{\mathrm{tm} 1 \mathrm{Ts}} / \mathrm{J}\right)$, identifying the cytokine as critical 
regulator of early host defense mechanisms against $M$. ulcerans infection. Compared to wildtype mice, IFN $\gamma$-deficient mice displayed a faster progression of the infection with increased tissue necrosis, increased edema formation and a higher bacterial burden [40]. These results were somewhat comparable with an earlier study that reported an increased susceptibility of IFN $\gamma$-deficient mice to an avirulent (mycolactone-negative) and an intermediately virulent $M$. ulcerans strain [41]. Studies in Rag $2^{-/-}$mice and nude mice done in the same laboratory in Portugal showed a year later that lymphocytes are protective against infection with lowvirulence strains but not against infection with highly virulent $M$. ulcerans [42].

Three more specialized transgenic mouse lines were used to study very specific questions in the mouse model for BU: Type 2 angiotensin II receptor knock-out mice $\left(\mathrm{AT}_{2} \mathrm{R},[43]\right)$ were used for studying nerve damage caused by mycolactone but the infection in those mice was not further characterized [44]. Similarly, Fas- and Bim-knock out (KO) mice were used to establish the mode of action of the toxin mycolactone in vivo [45]. Mice lacking the proapoptotic Bcl-2 family member Bim did not develop necrotic BU lesions, but were able to control the mycobacterial multiplication. Recently a study used ICR mice, an outbred strain, for infection with M. ulcerans in order to study questions of BU transmission [46].

\subsubsection{Mycobacterial Strains Used for Experimental Infection}

Compared to the mouse strains used in the foot pad model of BU, the M. ulcerans strains used to infect the mice are much more diverse. Again, preferences appear to be present in different laboratories, probably mostly dependent on which strains were available to the laboratory at some point in time and which strains could be maintained without loss of virulence. As repeated passage by in vitro culture prompts some of the $M$. ulcerans strains to lose their virulence plasmid [47, 48], some laboratories opted to passage their strains trough mouse foot pads in order to preserve their virulence [49-51]. Alternatively, low passage primary isolates have been used for productive infection of mice [52].

The most comprehensive study on how the use of $M$. ulcerans strains from different geographical origin and with different cultivation history influences virulence and immune responses induced in experimentally infected mice was published in 2009 by Ortiz et al. Eleven different $M$. ulcerans strains isolated from different parts of the world over a time span of 47 years were used to infect 6-8 weeks old male $\mathrm{BALB} / \mathrm{c}$ mice in the foot pad. Subsequently, their ability to cause a productive infection was reported as well as a detailed characterization of the inflammation induced by the different strains [53]. The bacterial strains used in these experiments partially overlap with the set of strains which was regularly used in the laboratory of Jorge Pedrosa, the only other research group that systematically characterized murine infection caused by different strains of M. ulcerans [30, 39, 41, 42, 48, 54]. The vast majority of BU mouse model studies were conducted with a single $M$. ulcerans strain. A few of those M. ulcerans isolates warrant mentioning as they are especially popular: Cu001 was originally isolated from a BU patient in Adzopé, Ivory Coast, in 1996 and has been successively passaged in foot pads of BALB/c mice ever since $[28,35]$. It is probably the strain most often used for in vivo 
antibiotic treatment efficacy testing. Mu1615 is among the oldest isolates frequently used in mouse infection studies. It was originally obtained from a Malaysian BU patient in the 1960s and produces mycolactone A/B like the African isolates [55, 56]. A spontaneous mycolactone negative mutant derived from this strain [47] has been used as avirulent $M$. ulcerans strain in the mouse model. S1013 was originally isolated in 2010 from a swab taken from the undermined edges of the ulcerative lesion of a Cameroonian BU patient [57]. Its passage number has been kept to an absolute minimum in order to preserve its virulence for studies in the mouse footpad model and the pig model of BU $[40,45,52,58-60]$.

\subsubsection{Dose and Preparation of the Bacterial Inocula}

Similarly to all the other experimental details of the BU mouse model described above, preparation of the inoculum, as well as how the number of bacteria in the inoculum is quantified varies from laboratory to laboratory. The waxy extracellular matrix of $M$. ulcerans together with the extreme slow growth of the bacteria are the two major factors that make preparation and dosing of an inoculum of $M$. ulcerans rather difficult. One strategy that some laboratories employ for dispersing clumps in their culture is to vortex the bacteria with glass beads prior to quantification of the inoculum $[30,32]$. Sonication of the culture is another possible way of reducing clumps. However, both methods pose the risk of substantially altering the surface structure of the bacilli and with it potentially their interaction with the host after inoculation.

For estimating the number of bacteria in the inoculum, colony forming unit (CFU) counting or counting of AFB by microscopy are the most commonly used methods. The AFB counting method according to Shepard and McRae [61] offers the advantage that the actual dose is quantified at the time of injection, while 2-3 months waiting time for colonies to grow is necessary after plating. On the other hand, CFU plating reveals the number of live $M$. ulcerans (or microclumps), which cannot be determined by microscopic enumeration. Hydrophobicity and the strong tendency of $M$. ulcerans to clump affect both methods, as well as dosing with the help of optical density (OD) or the so called McFarland standard [62]. Because an immediate estimate of how many bacteria are in a solution proved to be so difficult, some laboratories opted to produce cell banks of ready to go bacterial inocula that were frozen down for later use [63]. While this strategy allows to standardize inoculation, the freezing may affect to some extent relevant properties of the bacteria. In our hands, dosing the infection based on the wet weight of the bacterial pellet resulted in the most reproducible infection of mouse foot pads [34, $40,52,58]$. A wide range of inoculum sizes has been used. In some studies as few as a hundred or a thousand $\mathrm{CFU}[45,50,58]$ were injected, while others used up to $10^{5}$ or $10^{6} \mathrm{CFU}[54,64]$.

\subsubsection{Infection Outcomes and What to Measure}

With an estimated generation time of 3-4 days in the mouse foot pad [14], animal experiments with $M$. ulcerans often last for a long time. Depending on the infection dose and the virulence of the strain injected, development of a visible pathology only 
starts a few weeks after infection [14, 53], with a typical lag time of 3-4 weeks. When foot pads are inoculated, the first visible signs are usually edema on the top of the foot pad, followed by reddening of the foot and ankle and swelling to the point where foot pads appear to be "leaky", so that cage bedding material starts to stick to the foot pad (Fig. 1). Infected mouse ears do not tolerate high bacterial inocula and infection often results in rapid loss of tissue [34]. Similarly, mouse tails do not comprise a lot of fat, hence the ulceration described in publications where mice were infected in the tail might have limited comparability to human BU lesions [24].

Several approaches to monitor progression of the infection exist. Measuring foot pad thickness with a caliper allows for repeated measurements while assessment of bacterial proliferation by CFU plating, AFB counting, or qRT-PCR require the euthanasia of the animal. For CFU determination the infected tissue is usually ground up, sometimes de-contaminated to avoid overgrowth with faster growing microorganisms and further processed $[22,52]$. Very recently an optimized procedure for extraction and quantification of bacterial RNA from infected mouse tissue was published, which provides a surrogate marker for viability of the bacteria [66, 67]. Parallel to measuring foot pad thickness, a grading system can be applied to estimate the severity of the disease (Fig. 1). The grading system as it is used in many laboratories today was originally described in 1972 and has not substantially changed since then [20]. Both, grading system as well as foot pad thickness measurements have mostly replaced the practice of measuring time to death of the animals. Instead, animals are monitored on a regular basis and animals are euthanized in compliance with laws for protection of experimental animals. If enumeration of AFB or quantification of bacterial DNA is not the primary objective of the analysis, all infected tissues can be processed for histopathology instead, and a description of inflammatory cellular infiltrates, tissue damage, etc. can be done.

For in vivo monitoring of the infection, Zhang et al. engineered recombinant bioluminescent $M$. ulcerans strains expressing luxAB from Vibrio harveyi [68]. The
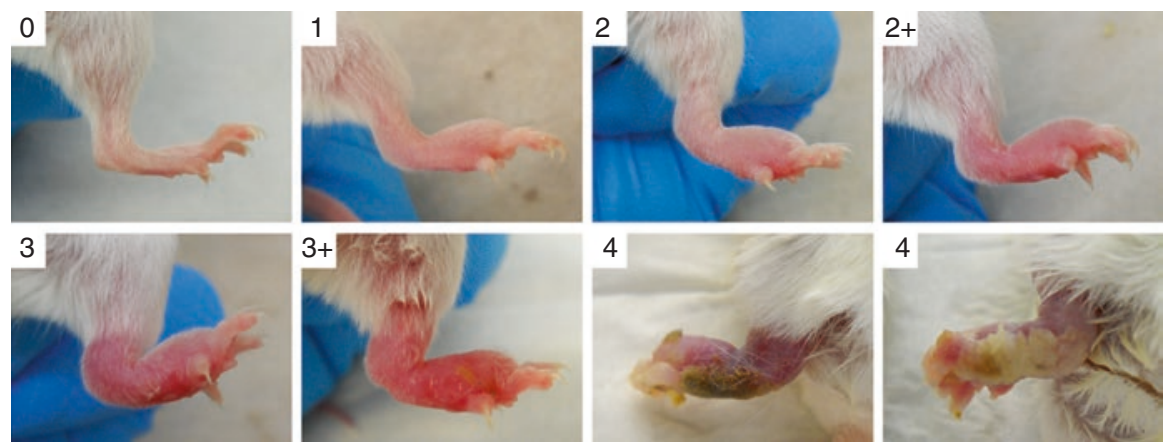

Fig. 1 Pathogenesis after subcutanous M. ulcerans injection in the mouse foot pad. Subcutaneous (s.c.) injection of acid fast bacilli into the healthy mouse foot pad (0) leads to progressive swelling and inflammation. (1) Grade 1, slight swelling; (2 and 2+) Grade 2, swelling with inflammation; (3 and 3+) Grade 3, swelling with inflammation of the leg; (4) Grade 4, swelling with inflammation and possible ulceration, cage bedding sticking to the sole of the foot [65] 
relative light unit count measured for these strains in real-time correlated with the CFU counts [68]. The measured bioluminescence represents a suitable real-time surrogate marker for viable bacteria in mouse foot pads [33]. While these first constructs required exogenous substrate, limiting their utility in vivo, Zhang et al. went on engineering alternative bacterial strains that are autoluminescent and showed that they could reduce time, effort, animal numbers and costs of BU animal model experiments [69].

Another rather new approach proposed for monitoring antibiotic treatment success is the detection of mycolactone by thin layer chromatography (TLC) or fluorescent TLC [70].

\subsection{Research Applications for the Mouse Model}

\subsubsection{Antimicrobial Compound Testing}

Antimicrobial compound testing is the application for which the BU mouse model was most frequently used since the discovery of the disease. Early on, researchers were interested in which antimicrobials would work against the newly described bacterium, which was the major incentive to have an animal model in the first place $[15,71,72]$. When the mouse model saw a revival in the early 2000 s, testing new drugs in vivo was still its main use.

Systematic testing of different antimicrobial treatments in the mouse foot pad model with Rifampin, Rifabutin, Amikacin (AMK), Clarithromycin (CLR) and Streptomycin (STR) being the most intensively evaluated actives, showed that a combination therapy with Rifampicin (RIF) and AMK or STR might be effective for the treatment of human BU $[28,35]$ and led to the conduction of a human treatment trial using RIF and STR [73]. Mice were usually treated right away from the day of infection and only when a potential effective combination of drugs was found, later treatment starts were evaluated [29, 74]. When doses were administered in different time intervals, it became very clear, that the effect on $M$. ulcerans was significantly stronger when mice were treated daily [75]. Therapy durations varied between studies, but were mostly between 4 and 8 weeks [28, 29, 35, 36, 74, 76, 77]. Finally, Lefrançois et al. showed in 2007 that combination treatment with RIF and an aminoglycoside (STR or AMK) was able to prevent BU in mice with 8 weeks being the optimal duration of treatment [78]. Since the provisional guidelines of the World Health Organization (WHO) in 2004, BU patients were treated with a combination of RIF and STR [79]. This proved to be an effective treatment for the disease; however, the fact that STR had to be injected daily was less than optimal. Hence, researchers started to look for a cure that could be administered as a fully oral regimen and tested them in the mouse model [80-82]. As shown by Ji et al. in 2007 the combination of RIF and CLR has the highest potential of replacing the current standard treatment [82]. The WHO Technical Advisory Group on BU decided in 2017 that the WHO recommendation for treatment of the disease should be changed to RIF and CLR, pending the availability of full results of a treatment trial with this drug combination. 
On a few occasions, treatment alternatives to drug administration were also tested in the BU mouse model: The effect of corticosteroid-induced immunosuppression on therapy with antibiotics was examined [83], phage therapy was shown to be effective in mice [54] and even the efficacy of hydrated clays on M. ulcerans growth was assessed in vivo on mouse tails [84]. However, as ideal the mouse model might be for drug testing and every therapy that can be applied by injection or orally, for the evaluation of topically applied therapies, including thermotherapy, the mouse model is highly impractical.

\subsubsection{Vaccine Development}

Including a vaccination phase prior to infection of mice with M. ulcerans further prolongs the overall time of the animal experiments, resulting in experiments that often last for several months. For example a single experiment including two immunizations with an adjuvanted formulation of recombinant protein followed by infection with a low dose of bacteria results in almost five months of experiment time, not counting the time needed for specimen processing and follow up analyses [58]. An important factor determining the time span is the time researchers allow between the last immunization and the infection with M. ulcerans. Three weeks is generally agreed on as the minimum waiting time, although some research laboratories have published longer intervals, lasting up to 16 weeks $[32,85]$. Mostly, protective efficacy of the tested vaccines is assessed by comparing the speed and severity of the infection between mice receiving the candidate vaccine and a placebo group, very similarly to testing of antimicrobial compounds, where non- or mock-treated animals are used as negative controls.

After a first attempt of protecting rats and mice with Mycobacterium fortuitum against experimental $M$. ulcerans infections in 1985 [86], vaccination against BU was not experimentally addressed for another 15 years. Evidence in the literature of a partial protective effect of Bacillus Calmette-Guérin (BCG) vaccination in humans against BU prompted the research group of Kris Huygen to experimentally address this question in the mouse model and to become the major driver of the search for a BU vaccine in the following years $[87,88]$. Tanghe et al. showed that intravenous vaccination with $\mathrm{BCG}\left(10^{6} \mathrm{CFU}\right)$ or intra-muscular vaccination with plasmid DNA encoding the $\mathrm{BCG}$ version of antigen 85A (Ag85A) both reduced the bacterial burden in foot pads of infected mice [32]. Although BCG vaccination has been repeatedly shown to reduce CFU numbers in experimentally infected mice and/or slow down pathogenesis $[24,48,51]$, the protection conferred by BCG was always only partial, of only relatively short duration and could not be prolonged by a booster vaccination [85]. Furthermore, a comparison between BALB/c mice and C57BL/6 mice revealed that the efficacy of BCG vaccination against $M$. ulcerans may vary with both choice of host and pathogen strain [27]. A single sub-cutaneous vaccination with a mycolactone-negative $M$. ulcerans strain two months prior to foot pad infection with a virulent isolate was found to lead to a similar delay in foot pad swelling as a single BCG immunization [48], countering arguments that a homologous immunization would be more efficient than a heterologous with the $M$. bovis derived BCG. Nevertheless, Hart et al. further pursued this approach with some 
success, as they were able to show that a prime vaccination with recombinant BCG expressing M. ulcerans Ag85A followed by a similar recombinant Mycobacterium smegmatis boost conferred superior protection against in vivo challenge than BCG alone [89]. While in this study immunizations were done intra-venously, the follow up study showed that a single sub-cutaneous injection with a BCG strain overexpressing two $M$. ulcerans antigens significantly prolonged survival times of mice compared to vaccination with the previously tested vaccination strains and application routes [63]. Even though the observed differences in bacterial burden at some point during the experiment were correlated with longer survival of the mice, none of the vaccination strategies tested so far was able to completely protect against experimental infection with $M$. ulcerans.

Besides DNA-vaccines [24, 32, 51, 90] and immunization with live BCG and/or mycolactone negative $M$. ulcerans, a few other attempts have been made at developing a vaccine against BU: Mice were exposed to Naucoris aquatic insect bites or sensitized to Naucoris salivary gland homogenates [26], immunized with recombinant virus replicon particles [52], adjuvanted recombinant proteins [58] or dewaxed whole-cell vaccines [64], all with limited protective efficacy at best.

\subsubsection{Study of the Pathogenesis of Buruli Ulcer and the Immune Response to the Disease}

While BU in humans results in different clinical presentations, pathogenesis in experimentally infected mice usually follows a defined pattern that is shaped by the virulence of the $M$. ulcerans strain used for infection. Two histopathological hallmarks of the human disease are the presence of large extracellular clusters of AFB and the almost complete absence of inflammatory infiltrates in the center of the lesions [91, 92], but not necessarily in the periphery of lesions [93]. While acquiring human tissue specimens from early BU cases is challenging due to practical and ethical reasons [93], the mouse model of M. ulcerans infection allowed to describe the early events in the pathogenesis of $M$. ulcerans infection in detail. In the mouse, at least some of the inoculated M. ulcerans bacteria are initially captured by phagocytes at the injection site and transported to the draining lymph node. The importance of initial intracellular stages prior to the emergence of extracellular clusters [22] is not entirely clear. Infection with virulent strains in mice then leads to the fast influx of neutrophils and to some degree of monocytes/macrophages, thus an early acute inflammatory response is induced [22, 30, 31]. Even though cellular responses are initiated in the draining lymph nodes, the progression from this initial acute to a more chronic inflammation with a predominance of mononuclear cells and/or lymphocytes is obstructed [30] because mycolactone is driving the cellular infiltrates into apoptosis. As a consequence AFB become extracellular and proliferate in the developing necrotic and acellular subcutaneous lesion. At the boundary between the expanding necrotic areas and the surrounding healthy tissue, acute inflammatory infiltrates and intracellular bacteria are found [30]. This belt of immune cells remains a site of constant interaction between the pathogen and the immune system. As the infection progresses in infected mouse foot pads, edema becomes a prominent feature in histopathology, which is 
macroscopically reflected by the onset of foot pad swelling [30, 31]. Swelling then extends to the ankle and the lower part of the leg, at which point mice are usually euthanized for ethical reasons [31]. Treatment of infected mice with RIF-STR rapidly leads to changes in the histopathological appearance of the infected tissue. The predominantly neutrophilic immune response changes to an infiltration dominated by lymphocytes and macrophages with prominent B-lymphocyte clusters and macrophage accumulations surrounding the bacteria, which loose solid Ziehl-Neelsen staining and viability [31, 94, 95].

Both, immune response and pathogenesis observed in $M$. ulcerans mouse infections are strongly influenced by the toxin mycolactone. Mycolactone-negative bacteria are faster phagocytosed, no prominent necrosis is developing and the initial neutrophilic response becomes readily replaced by a predominantly lymphocytic and macrophagic infiltrate $[22,30]$. Goto et al. examined whether nerve invasion occurred after infection of mouse foot pads with $M$. ulcerans and concluded, that the reported painlessness of BU might partially be attributed to intraneural invasion of bacilli [96]. Another study used injection of mycolactone rather than bacilli to study the effects of the toxin more directly in vivo [97].

\section{$3 \quad$ Other Animal Models}

\subsection{Guinea Pig (Cavia porcellus)}

Guinea pigs have been used as model for M. ulcerans infection as early as in 1974, when the presence of an exogenous diffusible toxin, nowadays known as mycolactone, was proposed $[98,99]$. Culture filtrate intradermally inoculated into guinea pig skin caused focal necrosis and inflammation, which closely resembled the skin lesions developing after injection of viable organisms as well as human BU skin lesions $[98,99]$. In later experiments the effect of extracted mycolactone was compared to the effects caused by infection of the skin with wild type and mycolactonedeficient $M$. ulcerans bacteria. It became clear that the histopathological effects observed were largely attributable to the polyketide toxin mycolactone, the main virulence factor of $M$. ulcerans, which induced apoptosis as demonstrated by TUNEL staining [100-102]. Macroscopic changes in the guinea pig after an intradermal injection of $10^{6}$ and $10^{7} \mathrm{M}$. ulcerans bacteria included the occurrence of a nodule after three days and the presence of ulcers after 8-12 days. Histopathological hallmarks were described as the occurrence of central necrotic areas with extracellular AFB, which enlarged during the six weeks observation time and were surrounded by inflammatory infiltrates [100]. Recovery and re-growth of bacteria from the skin lesions was possible until week six after infection, but viability decreased substantially during the observation period [100]. In a time-lapse study conducted by SilvaGomes et al. in which the ear and the back of the guinea pigs were subcutaneously inoculated, the early nodule-like structures progressed to ulcers with overlying scabs which healed between day 18-26 post-inoculation and were accompanied by bacterial clearance regardless of the strain or the infectious dose used [103]. 
One proposed potential way of contracting BU is the contamination of existing open wounds with $M$. ulcerans through exposure to a contaminated environment. In order to test this hypothesis, the skin of guinea pigs has been abraded and cultured M. ulcerans cells were applied on the open superficial wounds [104]. However, topical application failed to establish an infection during the 90 days of observation and all abrasion sites healed during the first week post exposure. In contrast, from all the sites intradermally injected with $10^{6} \mathrm{M}$. ulcerans bacteria as positive control, re-cultivation was possible 90 days post infection [104].

Overall, guinea pigs seem to be quite resistant to $M$. ulcerans infections, and are far less frequently used as BU research model than mice.

\subsection{Pig (Sus scrofa)}

The pig has only recently been evaluated as a model to study BU [59, 60]. Pig and human skin share many similarities like thickness, general structure of the epidermis, dermis and the subcutaneous tissue, blood supply and the adnexal structures [105-109]. Moreover, the porcine immune system resembles the human immune system much more than the murine immune system [110]. This has made the porcine skin a preferred model for burn and wound healing studies [111-113]. In the studies conducted by Bolz et al. that represent the first description of the pig (Sus scrofa) as a model to study $M$. ulcerans infection, eight week old piglets were infected subcutaneously with $100 \mu \mathrm{l}$ of different numbers $\left(2 \times 10^{3}\right.$ to $\left.2 \times 10^{7}\right)$ of $M$. ulcerans bacteria [60]. For injections, both flanks [59, 60] as well as the upper and lower legs (unpublished results) were used to study up to 24 individual inoculation sites on a single pig, which greatly reduces the number of animals needed for individual experiments. After 2.5 weeks macroscopic examinations revealed elevated, movable and firm nodular structures with the highest inoculation doses. After 6.5 weeks these lesions presented either as indurated plaques or had ulcerated. Histopathological analysis showed that all key features typically found in early human BU lesions [93] were also present in the pig 2.5 weeks after inoculation (Fig. 2) [60]. At the inoculation site a necrotic core structure containing mainly extracellular clusters of AFB (Fig. 2a) and fat cell ghosts developed. The core as well as some infiltrating cells were strongly stained by the TUNEL method (Fig. 2b), indicating the presence of large numbers of apoptotic cells. The necrotic core was surrounded by a dense belt of infiltrating cells, which were mainly composed of macrophages and CD3 positive T-cells (Fig. 2c) [59]. Inside the necrotic core debris of neutrophils was still detectable [59]. At week 6.5 the infiltration was even more organized, with the necrotic core being surrounded by a belt of neutrophils followed by a belt of macrophages and the outermost belt being mainly composed of CD3 positive T-cells. Some of the pig lesions had ulcerated during this observation time. Although the majority of bacteria and necrotic slough were expelled during that process, small necrotic areas with AFB remained and undermined edges started to form. A slight epidermal hyperplasia was already observed after 2.5 weeks, however at later time points it was much more pronounced [60]. 

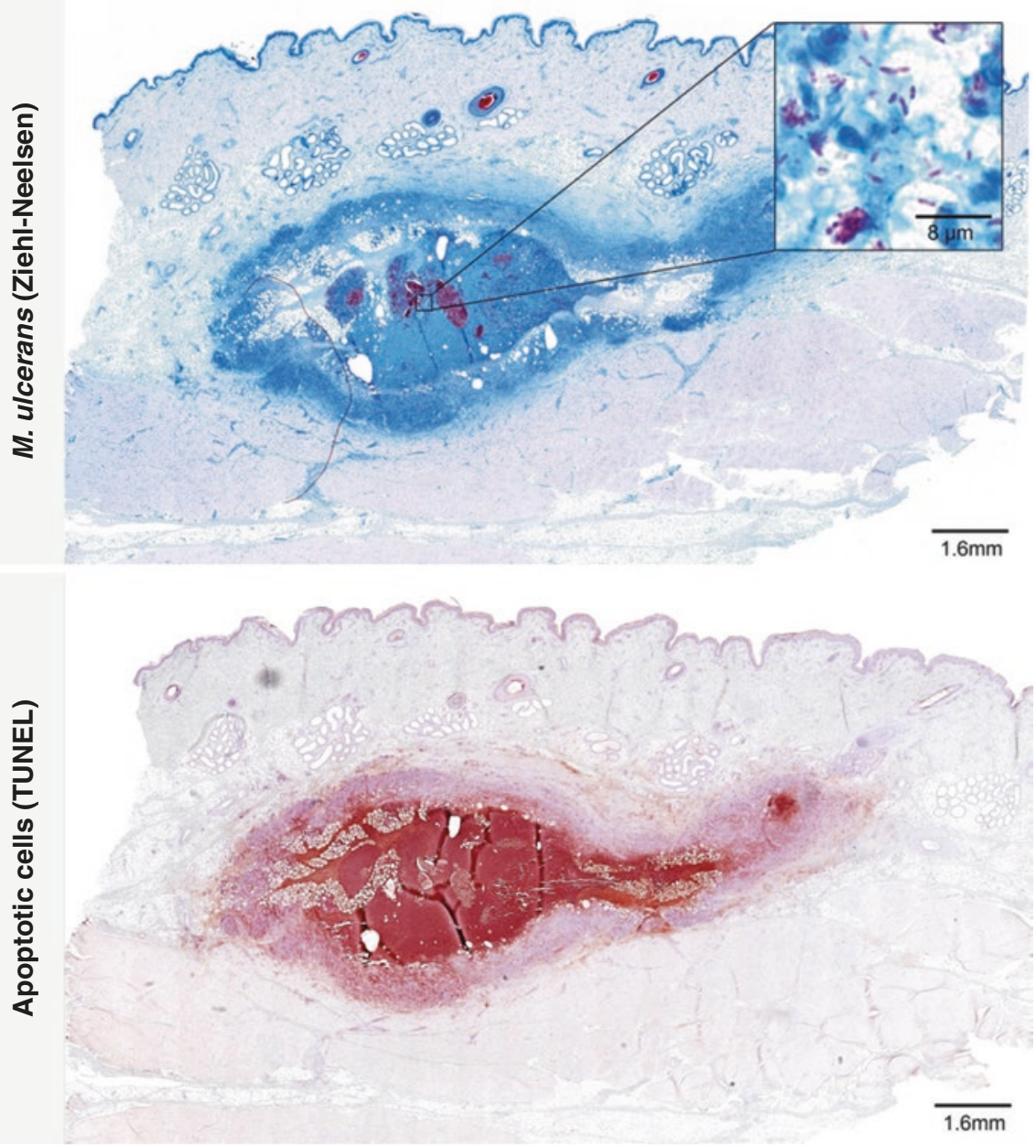

Fig. 2 Histopathological appearance of a typical pig BU lesion two weeks after subcutaneous injection of $7 \times 10^{7} \mathrm{M}$. ulcerans bacteria. (a) Ziehl-Neelsen staining revealed the presence of large extracellular clusters, globi like structures and single intra- and extracellular AFB (pink rods). (b) The TUNEL staining method for apoptotic cells revealed a strong staining of the necrotic core as well as some TUNEL positive cells in the surrounding infiltration belt. (c) CD3 positive T-cells are only present in the outermost area of the infiltration and start to form a belt around the lesion core, which develops further until week 6 


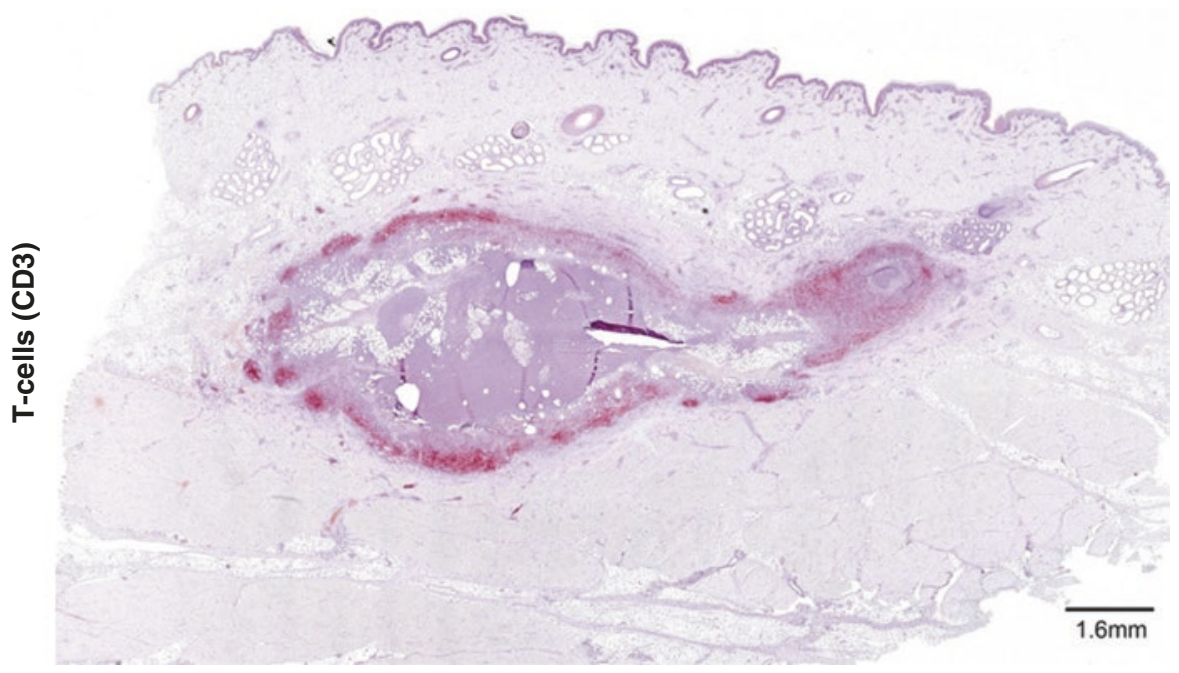

Fig. 2 (continued)

Injection of synthetic mycolactone into pig skin induced a comparable dose dependent effect in the tissue, with the formation of a necrotic core surrounded by inflammatory cells ([60] and unpublished results). In follow up studies cultivation of $M$. ulcerans bacteria re-isolated from infected pig skin was only possible up to 3 weeks after inoculation, and no chronic infection developed. The pig model thus seems to reproduce very well the early pathogenesis but not the chronic, necrotizing nature of human lesions.

\subsection{Grasscutter (Thryonomys swinderianus)}

Addo et al. [62] used the small hystricomorph rodent Thryonomys swinderianus, commonly called grasscutter, as a model for BU. The abundance of these animals in sub-Saharan Africa, the already existent establishment as laboratory animals and the substantially larger body size than mice $(1.5-5 \mathrm{~kg})$ were major reasons for choosing these animals. Grasscutters were subcutaneously inoculated into the shaved right thigh with $200 \mu \mathrm{l} \mathrm{M}$. ulcerans suspension (1.0 and 5.0 McFarland standards) [62]. Progressive skin lesions (erythema, papule, nodule, edema, and undermined ulcer) developed in all inoculated animals with onset and severity of the lesions correlating with the infection dose. After the development of a nodule and a scab (40 to 154 days after inoculation), which was demonstrated to contain AFB, infection stalled and an inactive phase (265 to 371 days) occurred. Relapse occurred 
in $90 \%$ of the animals and a fulminant progression of the disease with the formation of undermined ulcers was observed 441 to 540 days post inoculation. No systemic spread of bacteria was observed, with blood, urine and feces consistently being AFB-negative whilst the exudate and pus of the lesions was consistently AFBpositive. In histopathological analyses typical features of an M. ulcerans infection in the skin were observed together with rather untypically strong inflammation, neurogenic atrophy and osteomyelitis [62]. Re-cultivation of AFB from the infected animals however was not done and therefore viability of the AFB detected in exudate could not be determined.

\subsection{Anole Lizard (Anolis carolinensis)}

Based on the fact that M. ulcerans grows best at temperatures of $30-32{ }^{\circ} \mathrm{C}$, and poikilothermic animals have a preferred body temperature of $32{ }^{\circ} \mathrm{C}$, Marcus et al. tested the anole lizard, Anolis carolinensis, as a model to study BU $[114,115]$. Lizards were inoculated with an M. ulcerans solution containing $10^{3} \mathrm{CFU}$ into the right lateral thorax, caudal to the edge of the right scapula. Five times a week lizards were incubated at $32{ }^{\circ} \mathrm{C}$ for $6-8 \mathrm{~h}$. Six weeks post inoculation three different kind of lesions could be distinguished by histopathology [114]: a diffuse nonencapsulated, non-necrotizing granulomatous reaction with intracellular AFB (67\% of the animals), a diffuse necrotizing granulomatous myositis of the thoracic wall with large numbers of extracellular AFB (24\% of the animals) and the presence of several small, discrete, non-necrotizing encapsulated granulomas on the superficial surface of the supraspinatus nerve containing few intracellular AFB (4.8\% of the animals). Lizards inoculated with dead M. ulcerans bacteria also developed nonnecrotizing, non-encapsulated lesions, however, nearly all bacteria were found intracellularly. In contrast to the human disease, lesions did not develop inside the subcutaneous tissue but on the thoracic wall. Re-cultivated bacteria after single passage in the anole lizard showed a more rapid growth in vitro and were more virulent when introduced into mouse foot pads [114].

\subsection{Nine-Banded Armadillo (Dasypus novemcinctus)}

The nine-banded armadillo is a well-studied and characterized animal model in leprosy research [116] with a body temperature of $30-35.8^{\circ} \mathrm{C}$. Walsh et al. showed that it can also be used to study BU in vivo [117]. In this study animals were intradermally infected with $3 \times 10^{3}$ to $3 \times 10^{8} \mathrm{M}$. ulcerans into the lower abdominal and medial thigh regions. Injection sites were observed every 2-4 weeks for up to six months or death of the animal. $37 \%$ of the armadillos developed progressive cutaneous lesions, $15.5 \%$ developed evanescent papule-nodular lesions, $15.5 \%$ died within one week after inoculation and $32 \%$ of the animals developed no clinical signs [117]. Progressive cutaneous lesions presented with clinical signs comparable 
to the human disease like undermined edges and extensive necrosis. All animals which developed ulcers died between four and six months after inoculation due to unidentified reasons. Histopathologically, lesions showed coagulating necrosis of the deep dermis, panniculitis, edema, sparse inflammation, fat cell ghosts and AFB, mainly present as extracellular clumps. Three months after inoculation, cultures of one animal on Loewenstein-Jensen media were negative, although AFB were still present [117].

\subsection{Cynomologus Monkey (Maca fascicularis)}

In a study with only one monkey it was shown that intradermal inoculation of $M$. ulcerans $\left(2.2 \times 10^{8}\right)$ induced the formation of a papule which ulcerated within 2-4 weeks after inoculation [118]. In biopsies, infiltration, edema, inflammatory infiltrates and extracellular bacteria were observed. Ulcers healed spontaneously between eight and 12 weeks post infection. At week six, cultures on LoewensteinJensen medium were negative, indicating that the cynomolgus monkey is only modestly susceptible to M. ulcerans [118].

\subsection{African Rat (Mastomys natalensis)}

The common Africa rat was used by Singh and colleagues because of its abundance in sub-Saharan Africa. Inoculation of different doses into the tail vein led to ulceration and eventually the loss of the tail [119]. Supposedly due to the naturally suppressed immune system, internal organs (lung, spleen, liver) as well as the footpads were involved in a small number of individuals [119].

\subsection{Common Brushtail Possum (Trichosurus vulpecula)}

Due to the lower body temperature and a high susceptibility of Trichosurus vulpecula to $M$. tuberculosis and M. bovis, researchers infected these animals in two experimental series with $M$. ulcerans. Inoculation with patient material into the hind leg of one possum led to the formation of a deep ulcer. Material from this lesion was used to inoculate four more animals, subcutaneously or intraperitoneally. Cutaneous ulcers and lesions at peripheral sites developed and AFB were recovered from them $[120,121]$. In the second series it was shown that also non-inoculated T. vulpecula which were housed together with $M$. ulcerans inoculated animals developed ulcers from which AFB could be isolated [120]. Recent reports showed that wild possum species (Pseudocheirus peregrinus, Trichosurus vulpecula, Trichosurus cunninghami) in BU-endemic areas of Victoria, Australia are infected with M. ulcerans. Most clinically apparent cases were adults with ulcerative cutaneous lesions, generally confined to body areas without fur [4]. 


\section{$4 \quad$ Conclusions}

Overall, none of the currently used animal models fully reflects the spectrum of human BU disease. The mouse model is the most widely used animal model for BU in research because it is cheaper than the other models, bacteria are multiplying well and the onset of the disease is relatively fast. Especially for drug and vaccine studies, that both require large numbers of animals, this model is most advantageous. However, due to the lack of subcutaneous fat tissue and limited tissue depth, the clinical and histopathological appearance of the lesions in mouse foot pads and mouse tails are quite different from human BU lesions. In contrast, in the pig and guinea pig models both clinical and histopathological appearances of BU resemble the human situation, making both species a good model for the characterization of the early pathogenesis of BU. However both species are only modestly susceptible to $M$. ulcerans infection and do not develop chronic infections. All other animal models described in this chapter have not been studied well enough to conclude for which purposes they would be more suitable than the well-established mouse footpad model.

\section{References}

1. Mitchell PJ, Jerrett IV, Slee KJ (1984) Skin ulcers caused by Mycobacterium ulcerans in koalas near Bairnsdale, Australia. Pathology (Phila) 16:256-260

2. Mitchell PJ, McOrist S, Bilney R (1987) Epidemiology of Mycobacterium ulcerans infection in koalas (Phascolarctos cinereus) on Raymond Island, southeastern Australia. J Wildl Dis 23:386-390

3. Fyfe JAM, Lavender CJ, Handasyde KA, Legione AR, O'Brien CR, Stinear TP, Pidot SJ, Seemann T, Benbow ME, Wallace JR, McCowan C, Johnson PDR (2010) A major role for mammals in the ecology of Mycobacterium ulcerans. PLoS Negl Trop Dis 4:e791. https://doi. org/10.1371/journal.pntd.0000791

4. O'Brien CR, Handasyde KA, Hibble J, Lavender CJ, Legione AR, McCowan C, Globan M, Mitchell AT, McCracken HE, Johnson PDR, Fyfe JAM (2014) Clinical, microbiological and pathological findings of Mycobacterium ulcerans infection in three Australian possum species. PLoS Negl Trop Dis 8:e2666. https://doi.org/10.1371/journal.pntd.0002666

5. Carson C, Lavender CJ, Handasyde KA, O'Brien CR, Hewitt N, Johnson PDR, Fyfe JAM (2014) Potential wildlife sentinels for monitoring the endemic spread of human Buruli ulcer in South-East Australia. PLoS Negl Trop Dis 8:e2668. https://doi.org/10.1371/journal. pntd.0002668

6. O'Brien CR, McMillan E, Harris O, O'Brien DP, Lavender CJ, Globan M, Legione AR, Fyfe JA (2011) Localised Mycobacterium ulcerans infection in four dogs. Aust Vet J 89:506-510. https://doi.org/10.1111/j.1751-0813.2011.00850.x

7. Elsner L, Wayne J, O'Brien CR, McCowan C, Malik R, Hayman JA, Globan M, Lavender CJ, Fyfe JA (2008) Localised Mycobacterium ulcerans infection in a cat in Australia. J Feline Med Surg 10:407-412. https://doi.org/10.1016/j.jfms.2008.03.003

8. van Zyl A, Daniel J, Wayne J, McCowan C, Malik R, Jelfs P, Lavender CJ, Fyfe JA (2010) Mycobacterium ulcerans infections in two horses in South-Eastern Australia. Aust Vet $\mathrm{J}$ 88:101-106. https://doi.org/10.1111/j.1751-0813.2009.00544.x

9. O'Brien C, Kuseff G, McMillan E, McCowan C, Lavender C, Globan M, Jerrett I, Oppedisano F, Johnson P, Fyfe J (2013) Mycobacterium ulcerans infection in two alpacas. Aust Vet J 91:296-300. https://doi.org/10.1111/avj.12071 
10. Durnez L, Suykerbuyk P, Nicolas V, Barrière P, Verheyen E, Johnson CR, Leirs H, Portaels F (2010) Terrestrial small mammals as reservoirs of Mycobacterium ulcerans in Benin. Appl Environ Microbiol 76:4574-4577. https://doi.org/10.1128/AEM.00199-10

11. Portaels F, Chemlal K, Elsen P, Johnson PD, Hayman JA, Hibble J, Kirkwood R, Meyers WM (2001) Mycobacterium ulcerans in wild animals. Rev Sci Tech Int Off Epizoot 20: 252-264

12. Vandelannoote K, Durnez L, Amissah D, Gryseels S, Dodoo A, Yeboah S, Addo P, Eddyani M, Leirs H, Ablordey A, Portaels F (2010) Application of real-time PCR in Ghana, a Buruli ulcer-endemic country, confirms the presence of Mycobacterium ulcerans in the environment. FEMS Microbiol Lett 304:191-194. https://doi.org/10.1111/j.1574-6968.2010.01902.x

13. MacCallum P, Tolhurst JC (1948) A new mycobacterial infection in man. J Pathol Bacteriol 60:93-122

14. Fenner F (1956) The pathogenic behavior of Mycobacterium ulcerans and Mycobacterium balnei in the mouse and the developing chick embryo. Am Rev Tuberc 73:650-673

15. Leach RH, Fenner F (1954) Studies on Mycobacterium ulcerans and Mycobacterium balnei III. Growth in the semi-synthetic culture media of Dubos and drug sensitivity in vitro and in vivo. Aust J Exp Biol Med Sci 32:835-852

16. Feldman WH, Karlson AG (1957) Mycobacterium ulcerans infections; response to chemotherapy in mice. Am Rev Tuberc 75:266-279

17. Fenner F (1957) Homologous and heterologous immunity in infections of mice with Mycobacterium ulcerans and Mycobacterium balnei. Am Rev Tuberc 76:76-89

18. Feldman WH, Karlson AG, Herrick JF (1957) Mycobacterium ulcerans; pathogenesis of infection in mice, including determinations of dermal temperatures. Am J Pathol 33:1163-1179

19. Shepard CC (1960) The experimental disease that follows the injection of human leprosy bacilli into foot-pads of mice. J Exp Med 112:445-454

20. Stanford JL, Phillips I (1972) Rifampicin in experimental Mycobacterium ulcerans infection. J Med Microbiol 5:39-45. https://doi.org/10.1099/00222615-5-1-39

21. Ullmann U, Schubert GE, Kieninger G (1975) Bacteriological investigations and animal experiments with Mycobacterium ulcerans (Tübingen 1971) (author's transl). Zentralblatt Bakteriol Parasitenkd Infekt Hyg Erste Abt Orig Reihe Med Mikrobiol Parasitol 232: 318-327

22. Coutanceau E, Marsollier L, Brosch R, Perret E, Goossens P, Tanguy M, Cole ST, Small PLC, Demangel C (2005) Modulation of the host immune response by a transient intracellular stage of Mycobacterium ulcerans: the contribution of endogenous mycolactone toxin. Cell Microbiol 7:1187-1196. https://doi.org/10.1111/j.1462-5822.2005.00546.x

23. Ruf M-T, Bolz M, Vogel M, Bayi PF, Bratschi MW, Sopho GE, Yeboah-Manu D, Um Boock A, Junghanss T, Pluschke G (2016) Spatial distribution of Mycobacterium ulcerans in Buruli ulcer lesions: implications for laboratory diagnosis. PLoS Negl Trop Dis 10:e0004767. https:// doi.org/10.1371/journal.pntd.0004767

24. Coutanceau E, Legras P, Marsollier L, Reysset G, Cole ST, Demangel C (2006) Immunogenicity of Mycobacterium ulcerans Hsp65 and protective efficacy of a Mycobacterium leprae Hsp65-based DNA vaccine against Buruli ulcer. Microbes Infect 8:2075-2081. https://doi. org/10.1016/j.micinf.2006.03.009

25. Marion E, Jarry U, Cano C, Savary C, Beauvillain C, Robbe-Saule M, Preisser L, Altare F, Delneste Y, Jeannin P, Marsollier L (2016) FVB/N mice spontaneously heal ulcerative lesions induced by Mycobacterium ulcerans and switch M. Ulcerans into a low Mycolactone producer. J Immunol 196:2690-2698. https://doi.org/10.4049/jimmunol.1502194

26. Marsollier L, Deniaux E, Brodin P, Marot A, Wondje CM, Saint-André J-P, Chauty A, Johnson C, Tekaia F, Yeramian E, Legras P, Carbonnelle B, Reysset G, Eyangoh S, Milon G, Cole ST, Aubry J (2007) Protection against Mycobacterium ulcerans lesion development by exposure to aquatic insect saliva. PLoS Med 4:e64. https://doi.org/10.1371/journal.pmed.0040064

27. Converse PJ, Almeida DV, Nuermberger EL, Grosset JH (2011) BCG-mediated protection against Mycobacterium ulcerans infection in the mouse. PLoS Negl Trop Dis 5:e985. https:// doi.org/10.1371/journal.pntd.0000985 
28. Dega H, Robert J, Bonnafous P, Jarlier V, Grosset J (2000) Activities of several antimicrobials against Mycobacterium ulcerans infection in mice. Antimicrob Agents Chemother 44:2367-2372

29. Ji B, Lefrançois S, Robert J, Chauffour A, Truffot C, Jarlier V (2006) In vitro and in vivo activities of rifampin, streptomycin, amikacin, moxifloxacin, R207910, linezolid, and PA-824 against Mycobacterium ulcerans. Antimicrob Agents Chemother 50:1921-1926. https://doi. org/10.1128/AAC.00052-06

30. Oliveira MS, Fraga AG, Torrado E, Castro AG, Pereira JP, Filho AL, Milanezi F, Schmitt FC, Meyers WM, Portaels F, Silva MT, Pedrosa J (2005) Infection with Mycobacterium ulcerans induces persistent inflammatory responses in mice. Infect Immun 73:6299-6310. https://doi. org/10.1128/IAI.73.10.6299-6310.2005

31. Ruf M-T, Schütte D, Chauffour A, Jarlier V, Ji B, Pluschke G (2012) Chemotherapy-associated changes of histopathological features of Mycobacterium ulcerans lesions in a Buruli ulcer mouse model. Antimicrob Agents Chemother 56:687-696. https://doi.org/10.1128/ AAC.05543-11

32. Tanghe A, Content J, Van Vooren JP, Portaels F, Huygen K (2001) Protective efficacy of a DNA vaccine encoding antigen 85A from Mycobacterium bovis BCG against Buruli ulcer. Infect Immun 69:5403-5411

33. Zhang T, Li S-Y, Converse PJ, Almeida DV, Grosset JH, Nuermberger EL (2011) Using bioluminescence to monitor treatment response in real time in mice with Mycobacterium ulcerans infection. Antimicrob Agents Chemother 55:56-61. https://doi.org/10.1128/AAC.01260-10

34. Bénard A, Sala C, Pluschke G (2016) Mycobacterium ulcerans mouse model refinement for pre-clinical profiling of vaccine candidates. PLoS One 11:e0167059. https://doi.org/10.1371/ journal.pone.0167059

35. Bentoucha A, Robert J, Dega H, Lounis N, Jarlier V, Grosset J (2001) Activities of new macrolides and fluoroquinolones against Mycobacterium ulcerans infection in mice. Antimicrob Agents Chemother 45:3109-3112. https://doi.org/10.1128/AAC.45.11.3109-3112.2001

36. Dhople AM (2001) In vivo susceptibility of Mycobacterium ulcerans to KRM-1648, a new benzoxazinorifamycin, in comparison with rifampicin. Anti-mycobacterial activity of KRM1648. Arzneimittelforschung 51:501-505. https://doi.org/10.1055/s-0031-1300070

37. Marsollier L, Honoré N, Legras P, Manceau AL, Kouakou H, Carbonnelle B, Cole ST (2003a) Isolation of three Mycobacterium ulcerans strains resistant to rifampin after experimental chemotherapy of mice. Antimicrob Agents Chemother 47:1228-1232

38. Houngbédji MG, Boissinot M, Bergeron GM, Frenette J (2008) Subcutaneous injection of Mycobacterium ulcerans causes necrosis, chronic inflammatory response and fibrosis in skeletal muscle. Microbes Infect 10:1236-1243. https://doi.org/10.1016/j.micinf.2008.07.041

39. Torrado E, Adusumilli S, Fraga AG, Small PLC, Castro AG, Pedrosa J (2007) Mycolactonemediated inhibition of tumor necrosis factor production by macrophages infected with Mycobacterium ulcerans has implications for the control of infection. Infect Immun 75:39793988. https://doi.org/10.1128/IAI.00290-07

40. Bieri R, Bolz M, Ruf M-T, Pluschke G (2016) Interferon- $\boldsymbol{\gamma}$ is a crucial activator of early host immune defense against Mycobacterium ulcerans infection in mice. PLoS Negl Trop Dis 10:e004450. https://doi.org/10.1371/journal.pntd.0004450

41. Torrado E, Fraga AG, Logarinho E, Martins TG, Carmona JA, Gama JB, Carvalho MA, Proença F, Castro AG, Pedrosa J (2010) IFN-gamma-dependent activation of macrophages during experimental infections by Mycobacterium ulcerans is impaired by the toxin mycolactone. J Immunol 184:947-955. https://doi.org/10.4049/jimmunol.0902717

42. Fraga AG, Cruz A, Martins TG, Torrado E, Saraiva M, Pereira DR, Meyers WM, Portaels F, Silva MT, Castro AG, Pedrosa J (2011) Mycobacterium ulcerans triggers T-cell immunity followed by local and regional but not systemic immunosuppression. Infect Immun 79:421-430. https://doi.org/10.1128/IAI.00820-10

43. Hein L, Barsh GS, Pratt RE, Dzau VJ, Kobilka BK (1995) Behavioural and cardiovascular effects of disrupting the angiotensin II type-2 receptor in mice. Nature 377:744-747. https:// doi.org/10.1038/377744a0 
44. Marion E, Song O-R, Christophe T, Babonneau J, Fenistein D, Eyer J, Letournel F, Henrion D, Clere N, Paille V, Guérineau NC, Saint André J-P, Gersbach P, Altmann K-H, Stinear TP, Comoglio Y, Sandoz G, Preisser L, Delneste Y, Yeramian E, Marsollier L, Brodin P (2014) Mycobacterial toxin induces analgesia in Buruli ulcer by targeting the angiotensin pathways. Cell 157:1565-1576. https://doi.org/10.1016/j.cell.2014.04.040

45. Bieri R, Scherr N, Ruf M-T, Dangy J-P, Gersbach P, Gehringer M, Altmann K-H, Pluschke G (2017) The macrolide toxin mycolactone promotes Bim-dependent apoptosis in Buruli ulcer through inhibition of mTOR. ACS Chem Biol 12:1297-1307. https://doi.org/10.1021/ acschembio.7b00053

46. Azumah BK, Addo PG, Dodoo A, Awandare G, Mosi L, Boakye DA, Wilson MD (2017) Experimental demonstration of the possible role of Acanthamoeba polyphaga in the infection and disease progression in Buruli ulcer (BU) using ICR mice. PLoS One 12:e0172843. https:// doi.org/10.1371/journal.pone.0172843

47. Dufresne SS, Frenette J (2013) Investigation of wild-type and mycolactone-negative mutant Mycobacterium ulcerans on skeletal muscle: IGF-1 protects against mycolactone-induced muscle catabolism. Am J Physiol Regul Integr Comp Physiol 304:R753-R762. https://doi. org/10.1152/ajpregu.00587.2012

48. Fraga AG, Martins TG, Torrado E, Huygen K, Portaels F, Silva MT, Castro AG, Pedrosa J (2012) Cellular immunity confers transient protection in experimental Buruli ulcer following BCG or mycolactone-negative Mycobacterium ulcerans vaccination. PLoS One 7:e33406. https://doi.org/10.1371/journal.pone.0033406

49. Chauffour A, Robert J, Veziris N, Aubry A, Jarlier V (2016) Sterilizing activity of fully oral intermittent regimens against Mycobacterium ulcerans infection in mice. PLoS Negl Trop Dis 10:e0005066. https://doi.org/10.1371/journal.pntd.0005066

50. Converse PJ, Tyagi S, Xing Y, Li S-Y, Kishi Y, Adamson J, Nuermberger EL, Grosset JH (2015) Efficacy of rifampin plus clofazimine in a murine model of Mycobacterium ulcerans disease. PLoS Negl Trop Dis 9:e0003823. https://doi.org/10.1371/journal.pntd.0003823

51. Tanghe A, Dangy J-P, Pluschke G, Huygen K (2008) Improved protective efficacy of a speciesspecific DNA vaccine encoding mycolyl-transferase Ag85A from Mycobacterium ulcerans by homologous protein boosting. PLoS Negl Trop Dis 2:e199. https://doi.org/10.1371/journal. pntd.0000199

52. Bolz M, Kerber S, Zimmer G, Pluschke G (2015) Use of recombinant virus replicon particles for vaccination against Mycobacterium ulcerans disease. PLoS Negl Trop Dis 9:e0004011. https://doi.org/10.1371/journal.pntd.0004011

53. Ortiz RH, Leon DA, Estevez HO, Martin A, Herrera JL, Romo LF, Portaels F, Pando RH (2009) Differences in virulence and immune response induced in a murine model by isolates of Mycobacterium ulcerans from different geographic areas. Clin Exp Immunol 157:271-281. https://doi.org/10.1111/j.1365-2249.2009.03941.x

54. Trigo G, Martins TG, Fraga AG, Longatto-Filho A, Castro AG, Azeredo J, Pedrosa J (2013) Phage therapy is effective against infection by Mycobacterium ulcerans in a murine footpad model. PLoS Negl Trop Dis 7:e2183. https://doi.org/10.1371/journal.pntd.0002183

55. Mve-Obiang A, Lee RE, Umstot ES, Trott KA, Grammer TC, Parker JM, Ranger BS, Grainger R, Mahrous EA, Small PLC (2005) A newly discovered mycobacterial pathogen isolated from laboratory colonies of Xenopus species with lethal infections produces a novel form of mycolactone, the Mycobacterium ulcerans macrolide toxin. Infect Immun 73:3307-3312. https:// doi.org/10.1128/IAI.73.6.3307-3312.2005

56. Pettit JH, Marchette NJ, Rees RJ (1966) Mycobacterium ulcerans infection. Clinical and bacteriological study of the first cases recognized in South East Asia. Br J Dermatol 78:187-197

57. Bratschi MW, Bolz M, Minyem JC, Grize L, Wantong FG, Kerber S, Njih Tabah E, Ruf M-T, Mou F, Noumen D, Um Boock A, Pluschke G (2013) Geographic distribution, age pattern and sites of lesions in a cohort of Buruli ulcer patients from the Mapé Basin of Cameroon. PLoS Negl Trop Dis 7:e2252. https://doi.org/10.1371/journal.pntd.0002252

58. Bolz M, Bénard A, Dreyer AM, Kerber S, Vettiger A, Oehlmann W, Singh M, Duthie MS, Pluschke G (2016a) Vaccination with the surface proteins MUL_2232 and MUL_3720 of 
Mycobacterium ulcerans induces antibodies but fails to provide protection against Buruli ulcer. PLoS Negl Trop Dis 10:e0004431. https://doi.org/10.1371/journal.pntd.0004431

59. Bolz M, Ruggli N, Borel N, Pluschke G, Ruf M-T (2016b) Local cellular immune responses and pathogenesis of Buruli ulcer lesions in the experimental Mycobacterium ulcerans pig infection model. PLoS Negl Trop Dis 10:e0004678. https://doi.org/10.1371/journal.pntd.0004678

60. Bolz M, Ruggli N, Ruf M-T, Ricklin ME, Zimmer G, Pluschke G (2014) Experimental infection of the pig with Mycobacterium ulcerans: a novel model for studying the pathogenesis of Buruli ulcer disease. PLoS Negl Trop Dis 8:e2968. https://doi.org/10.1371/journal. pntd.0002968

61. Shepard CC, McRae DH (1968) A method for counting acid-fast bacteria. Int J Lepr Mycobact Dis Off Organ Int Lepr Assoc 36:78-82

62. Addo P, Adu-Addai B, Quartey M, Abbas M, Okang I, Owusu E, Ofori-Adjei D, Awumbila B (2006) Clinical and histopathological presentation of Buruli ulcer in experimentally infected Grasscutters (Thryonomys swinderianus). Internet J Trop Med 3:e2

63. Hart BE, Lee S (2016) Overexpression of a Mycobacterium ulcerans Ag85B-EsxH fusion protein in recombinant BCG improves experimental Buruli ulcer vaccine efficacy. PLoS Negl Trop Dis 10:e0005229. https://doi.org/10.1371/journal.pntd.0005229

64. Watanabe M, Nakamura H, Nabekura R, Shinoda N, Suzuki E, Saito H (2015) Protective effect of a dewaxed whole-cell vaccine against Mycobacterium ulcerans infection in mice. Vaccine 33:2232-2239. https://doi.org/10.1016/j.vaccine.2015.03.046

65. Bolz M (2014) Prospects for the development of a subunit vaccine against Mycobacterium ulcerans disease (Buruli ulcer). PhD, University of Basel

66. Robbe-Saule M, Babonneau J, Sismeiro O, Marsollier L, Marion E (2017) An optimized method for extracting bacterial RNA from mouse skin tissue colonized by Mycobacterium ulcerans. Front Microbiol 8:512. https://doi.org/10.3389/fmicb.2017.00512

67. Sarpong-Duah M, Frimpong M, Beissner M, Saar M, Laing K, Sarpong F, Loglo AD, Abass KM, Frempong M, Sarfo FS, Bretzel G, Wansbrough-Jones M, Phillips RO (2017) Clearance of viable Mycobacterium ulcerans from Buruli ulcer lesions during antibiotic treatment as determined by combined 16S rRNA reverse transcriptase/IS 2404 qPCR assay. PLoS Neg1 Trop Dis 11:e0005695. https://doi.org/10.1371/journal.pntd.0005695

68. Zhang T, Bishai WR, Grosset JH, Nuermberger EL (2010) Rapid assessment of antibacterial activity against Mycobacterium ulcerans by using recombinant luminescent strains. Antimicrob Agents Chemother 54:2806-2813. https://doi.org/10.1128/AAC.00400-10

69. Zhang T, Li S-Y, Converse PJ, Grosset JH, Nuermberger EL (2013) Rapid, serial, non-invasive assessment of drug efficacy in mice with autoluminescent Mycobacterium ulcerans infection. PLoS Negl Trop Dis 7:e2598. https://doi.org/10.1371/journal.pntd.0002598

70. Converse PJ, Xing Y, Kim KH, Tyagi S, Li S-Y, Almeida DV, Nuermberger EL, Grosset JH, Kishi Y (2014) Accelerated detection of mycolactone production and response to antibiotic treatment in a mouse model of Mycobacterium ulcerans disease. PLoS Negl Trop Dis 8:e2618. https://doi.org/10.1371/journal.pntd.0002618

71. Lunn HF, Rees RJW (1964) Treatment of mycobacterial skin ulcers in Uganda with a riminophenazine derivative (B.663). Lancet 283:247-249. https://doi.org/10.1016/ S0140-6736(64)92351-7

72. Pattyn SR, Royackers J (1965) Treatment of experimental infection by Mycobacterium ulcerans and Mycobacterium balnei in mice. Ann Soc Belg Med Trop Parasitol Mycol 45: 31-38

73. Etuaful S, Carbonnelle B, Grosset J, Lucas S, Horsfield C, Phillips R, Evans M, Ofori-Adjei D, Klustse E, Owusu-Boateng J, Amedofu GK, Awuah P, Ampadu E, Amofah G, Asiedu K, Wansbrough-Jones M (2005) Efficacy of the combination rifampin-streptomycin in preventing growth of Mycobacterium ulcerans in early lesions of Buruli ulcer in humans. Antimicrob Agents Chemother 49:3182-3186. https://doi.org/10.1128/AAC.49.8.3182-3186.2005

74. Marsollier L, Prévot G, Honoré N, Legras P, Manceau AL, Payan C, Kouakou H, Carbonnelle B (2003b) Susceptibility of Mycobacterium ulcerans to a combination of amikacin/rifampicin. Int J Antimicrob Agents 22:562-566 
75. Dega H, Bentoucha A, Robert J, Jarlier V, Grosset J (2002) Bactericidal activity of rifampin-amikacin against Mycobacterium ulcerans in mice. Antimicrob Agents Chemother 46:3193-3196

76. Dhople AM, Namba K (2003) Activities of sitafloxacin (DU-6859a), either singly or in combination with rifampin, against Mycobacterium ulcerans infection in mice. J Chemother 15:4752. https://doi.org/10.1179/joc.2003.15.1.47

77. Nakanaga K, Saito H, Ishii N, Goto M (2004) Comparison of inhibitory effect of rifalazil and rifampicin against Mycobacterium ulcerans infection induced in mice. Kekkaku 79:333-339

78. Lefrançois S, Robert J, Chauffour A, Ji B, Jarlier V (2007) Curing Mycobacterium ulcerans infection in mice with a combination of rifampin-streptomycin or rifampin-amikacin. Antimicrob Agents Chemother 51:645-650. https://doi.org/10.1128/AAC.00821-06

79. WHO and GBU Initiative (2004) Provisional guidance on the role of specific antibiotics in the management of Mycobacterium ulcerans disease (Buruli ulcer). WHO and GBU Initiative, Geneva, Switzerland

80. Almeida D, Converse PJ, Ahmad Z, Dooley KE, Nuermberger EL, Grosset JH (2011) Activities of rifampin, rifapentine and clarithromycin alone and in combination against mycobacterium ulcerans disease in mice. PLoS Negl Trop Dis 5:e933. https://doi.org/10.1371/journal.pntd.0000933

81. Ji B, Chauffour A, Robert J, Jarlier V (2008) Bactericidal and sterilizing activities of several orally administered combined regimens against Mycobacterium ulcerans in mice. Antimicrob Agents Chemother 52:1912-1916. https://doi.org/10.1128/AAC.00193-08

82. Ji B, Chauffour A, Robert J, Lefrançois S, Jarlier V (2007) Orally administered combined regimens for treatment of Mycobacterium ulcerans infection in mice. Antimicrob Agents Chemother 51:3737-3739. https://doi.org/10.1128/AAC.00730-07

83. Martins TG, Trigo G, Fraga AG, Gama JB, Longatto-Filho A, Saraiva M, Silva MT, Castro AG, Pedrosa J (2012b) Corticosteroid-induced immunosuppression ultimately does not compromise the efficacy of antibiotherapy in murine Mycobacterium ulcerans infection. PLoS Negl Trop Dis 6:e1925. https://doi.org/10.1371/journal.pntd.0001925

84. Adusumilli S, Haydel SE (2016) In vitro antibacterial activity and in vivo efficacy of hydrated clays on Mycobacterium ulcerans growth. BMC Complement Altern Med 16:40. https://doi. org/10.1186/s12906-016-1020-5

85. Tanghe A, Adnet P-Y, Gartner T, Huygen K (2007) A booster vaccination with Mycobacterium bovis $\mathrm{BCG}$ does not increase the protective effect of the vaccine against experimental Mycobacterium ulcerans infection in mice. Infect Immun 75:2642-2644. https://doi. org/10.1128/IAI.01622-06

86. Singh NB, Srivastava A (1985) Mycobacterium fortuitum (TMC 1529): potentially immunogenic strain against experimental infections of Mycobacterium ulcerans in rats and mice. Indian J Exp Biol 23:408-409

87. Einarsdottir T, Huygen K (2011) Buruli ulcer. Hum Vaccin 7:1198-1203. https://doi. org/10.4161/hv.7.11.17751

88. Huygen K, Adjei O, Affolabi D, Bretzel G, Demangel C, Fleischer B, Johnson RC, Pedrosa J, Phanzu DM, Phillips RO, Pluschke G, Siegmund V, Singh M, van der Werf TS, WansbroughJones M, Portaels F (2009) Buruli ulcer disease: prospects for a vaccine. Med Microbiol Immunol 198:69-77. https://doi.org/10.1007/s00430-009-0109-6

89. Hart BE, Hale LP, Lee S (2015) Recombinant BCG expressing Mycobacterium ulcerans Ag85A imparts enhanced protection against experimental Buruli ulcer. PLoS Negl Trop Dis 9:e0004046. https://doi.org/10.1371/journal.pntd.0004046

90. Roupie V, Pidot SJ, Einarsdottir T, Van Den Poel C, Jurion F, Stinear TP, Huygen K (2014) Analysis of the vaccine potential of plasmid DNA encoding nine mycolactone polyketide synthase domains in Mycobacterium ulcerans infected mice. PLoS Negl Trop Dis 8:e2604. https://doi.org/10.1371/journal.pntd.0002604

91. Guarner J, Bartlett J, Whitney EAS, Raghunathan PL, Stienstra Y, Asamoa K, Etuaful S, Klutse E, Quarshie E, van der Werf TS, van der Graaf WTA, King CH, Ashford DA (2003) Histopathologic features of Mycobacterium ulcerans infection. Emerg Infect Dis 9:651-656 
92. Hayman J (1993) Out of Africa: observations on the histopathology of Mycobacterium ulcerans infection. J Clin Pathol 46:5-9

93. Ruf M-T, Steffen C, Bolz M, Schmid P, Pluschke G (2017) Infiltrating leukocytes surround early Buruli ulcer lesions, but are unable to reach the mycolactone producing mycobacteria. Virulence 8:1918-1926. https://doi.org/10.1080/21505594.2017.1370530

94. Martins TG, Gama JB, Fraga AG, Saraiva M, Silva MT, Castro AG, Pedrosa J (2012a) Local and regional re-establishment of cellular immunity during curative antibiotherapy of murine Mycobacterium ulcerans infection. PLoS One 7:e32740. https://doi.org/10.1371/journal. pone. 0032740

95. Sarfo FS, Converse PJ, Almeida DV, Zhang J, Robinson C, Wansbrough-Jones M, Grosset JH (2013) Microbiological, histological, immunological, and toxin response to antibiotic treatment in the mouse model of Mycobacterium ulcerans disease. PLoS Negl Trop Dis 7:e2101. https://doi.org/10.1371/journal.pntd.0002101

96. Goto M, Nakanaga K, Aung T, Hamada T, Yamada N, Nomoto M, Kitajima S, Ishii N, Yonezawa S, Saito H (2006) Nerve damage in Mycobacterium ulcerans-infected mice: probable cause of painlessness in buruli ulcer. Am J Pathol 168:805-811. https://doi.org/10.2353/ ajpath.2006.050375

97. En J, Goto M, Nakanaga K, Higashi M, Ishii N, Saito H, Yonezawa S, Hamada H, Small PLC (2008) Mycolactone is responsible for the painlessness of Mycobacterium ulcerans infection (Buruli ulcer) in a murine study. Infect Immun 76:2002-2007. https://doi.org/10.1128/ IAI.01588-07

98. Krieg RE, Hockmeyer WT, Connor DH (1974) Toxin of Mycobacterium ulcerans. Production and effects in Guinea pig skin. Arch Dermatol 110:783-788

99. Read JK, Heggie CM, Meyers WM, Connor DH (1974) Cytotoxic activity of Mycobacterium ulcerans. Infect Immun 9:1114-1122

100. Adusumilli S, Mve-Obiang A, Sparer T, Meyers W, Hayman J, Small PLC (2005) Mycobacterium ulcerans toxic macrolide, mycolactone modulates the host immune response and cellular location of M. ulcerans in vitro and in vivo. Cell Microbiol 7:1295-1304. https:// doi.org/10.1111/j.1462-5822.2005.00557.x

101. George KM, Chatterjee D, Gunawardana G, Welty D, Hayman J, Lee R, Small PL (1999) Mycolactone: a polyketide toxin from Mycobacterium ulcerans required for virulence. Science 283:854-857

102. George KM, Pascopella L, Welty DM, Small PL (2000) A Mycobacterium ulcerans toxin, mycolactone, causes apoptosis in Guinea pig ulcers and tissue culture cells. Infect Immun 68:877-883

103. Silva-Gomes R, Marcq E, Trigo G, Gonçalves CM, Longatto-Filho A, Castro AG, Pedrosa J, Fraga AG (2015) Spontaneous healing of Mycobacterium ulcerans lesions in the Guinea pig model. PLoS Negl Trop Dis 9:e0004265. https://doi.org/10.1371/journal.pntd.0004265

104. Williamson HR, Mosi L, Donnell R, Aqqad M, Merritt RW, Small PLC (2014) Mycobacterium ulcerans fails to infect through skin abrasions in a Guinea pig infection model: implications for transmission. PLoS Negl Trop Dis 8:e2770. https://doi.org/10.1371/journal.pntd.0002770

105. Hammond SA, Tsonis C, Sellins K, Rushlow K, Scharton-Kersten T, Colditz I, Glenn GM (2000) Transcutaneous immunization of domestic animals: opportunities and challenges. Adv Drug Deliv Rev 43:45-55

106. Liu Y, Chen J, Shang H, Liu C, Wang Y, Niu R, Wu J, Wei H (2010) Light microscopic, electron microscopic, and immunohistochemical comparison of Bama minipig (Sus scrofa domestica) and human skin. Comp Med 60:142-148

107. Mahl JA, Vogel BE, Court M, Kolopp M, Roman D, Nogués V (2006) The minipig in dermatotoxicology: methods and challenges. Exp Toxicol Pathol Off J Ges Toxikol Pathol 57:341345. https://doi.org/10.1016/j.etp.2006.03.004

108. Meyer W, Schwarz R, Neurand K (1978) The skin of domestic mammals as a model for the human skin, with special reference to the domestic pig. Curr Probl Dermatol 7:39-52

109. Montagna W, Yun JS (1964) The skin of the domestic pig. J Invest Dermatol 42:11-21 
110. Summerfield A, Meurens F, Ricklin ME (2015) The immunology of the porcine skin and its value as a model for human skin. Mol Immunol 66:14-21. https://doi.org/10.1016/j. molimm.2014.10.023

111. Jung Y, Son D, Kwon S, Kim J, Han K (2013) Experimental pig model of clinically relevant wound healing delay by intrinsic factors. Int Wound J 10:295-305. https://doi. org/10.1111/j.1742-481X.2012.00976.X

112. Sheu S-Y, Wang W-L, Fu Y-T, Lin S-C, Lei Y-C, Liao J-H, Tang N-Y, Kuo T-F, Yao C-H (2014) The pig as an experimental model for mid-dermal burns research. Burns J Int Soc Burn Inj 40:1679-1688. https://doi.org/10.1016/j.burns.2014.04.023

113. Sullivan TP, Eaglstein WH, Davis SC, Mertz P (2001) The pig as a model for human wound healing. Wound Repair Regen Off Publ Wound Heal Soc Eur Tissue Repair Soc 9:66-76

114. Marcus LC, Stottmeier KD, Morrow RH (1975) Experimental infection of anole lizards (Anolis carolinensis) with Mycobacterium ulcerans by the subcutaneous route. Am J Trop Med Hyg 24:649-655

115. Marcus LC, Stottmeier KD, Morrow RH (1976) Experimental alimentary infection of anole lizards (Anolis carolinensis) with Mycobacterium ulcerans. Am J Trop Med Hyg 25:630-632

116. Walsh GP, Meyers WM, Binford CH (1986) Naturally acquired leprosy in the nine-banded armadillo: a decade of experience 1975-1985. J Leukoc Biol 40:645-656

117. Walsh DS, Meyers WM, Krieg RE, Walsh GP (1999) Transmission of Mycobacterium ulcerans to the nine-banded armadillo. Am J Trop Med Hyg 61:694-697

118. Walsh DS, Dela Cruz EC, Abalos RM, Tan EV, Walsh GP, Portaels F, Meyers WM (2007) Clinical and histologic features of skin lesions in a cynomolgus monkey experimentally infected with Mycobacterium ulcerans (Buruli ulcer) by intradermal inoculation. Am J Trop Med Hyg 76:132-134

119. Singh NB, Srivastava A, Verma VK, Kumar A, Gupta SK (1984) Mastomys natalensis: a new animal model for Mycobacterium ulcerans research. Indian J Exp Biol 7:393-394

120. Bolliger A, Forbes BRV, Kirkland WB (1950) Transmission of a recently isolated mycobacterium to phalangers (Tichosurus vulpecula). Aust J Sci 12:146-147

121. Forbes BR, Wannan JS, Kirkland WB (1954) Indolent cutaneous ulceration due to infection with Mycobacterium ulcerans. Med J Aust 41:475-479

Open Access This chapter is licensed under the terms of the Creative Commons Attribution 4.0 International License (http://creativecommons.org/licenses/by/4.0/), which permits use, sharing, adaptation, distribution and reproduction in any medium or format, as long as you give appropriate credit to the original author(s) and the source, provide a link to the Creative Commons license and indicate if changes were made.

The images or other third party material in this chapter are included in the chapter's Creative Commons license, unless indicated otherwise in a credit line to the material. If material is not included in the chapter's Creative Commons license and your intended use is not permitted by statutory regulation or exceeds the permitted use, you will need to obtain permission directly from the copyright holder.

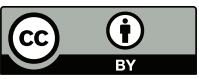

